\title{
Cash injection set to revive Swiss drug site
}

\section{Merck Serono facility could become biotech research hub.}

\section{BY DANIEL CRESSEY}

$\mathrm{O}$ ne of the largest philanthropic donations in European research history could give some former pharmaceutical-company laboratories fresh life as a centre for bioengineering.

In April, German pharmaceutical company Merck KGaA announced that it was closing the headquarters of Merck Serono, its drug-development unit based in Geneva, Switzerland, as part of a restructuring effort that cut about 500 jobs.

But last week, Swiss billionaire businessmen Hansjörg Wyss and Ernesto Bertarelli rode to the rescue with an undisclosed offer to buy the 45,000 -square-metre site close to the shores of Lake Geneva. They plan to give the laboratory facilities to the University of Geneva and the Swiss Federal Institute of Technology in Lausanne (EPFL), under the umbrella of a new Wyss Institute, and would fund research at the institute with a donation of 125 million Swiss francs (US $\$ 133.9$ million) over six years.

"We've seen a lot of these gifts going to the United States," says Patrick Aebischer, president of the EPFL, but donations of this size are vanishingly rare in Europe. A 2011 report from the European Commission, for example, noted that "philanthropic fundraising is not, on the whole, taken seriously in European universities" (B. Breeze et al. Giving In Evidence European Commission; 2011).

The Swiss Wyss Institute would house about ten life-science laboratories, led by new research chairs affiliated to the universities, and would provide jobs for up to 150 people. Merck Serono's state-of-the-art laboratories would not need to be refitted, says JeanDominique Vassalli, rector of the University of Geneva, so "I would guess within six months or a year we can have people moving in and working there. That's an extraordinary opportunity." The labs would focus on areas of overlap between medical research and engineering, such as tissue regeneration, implants and transplants.

Start-ups and other biotechnology businesses could also be hosted on the site, which is close to many existing companies. Wyss and $\rightarrow$ NATURE.COM

Read more about philanthropy and science: go.nature.com/biq27t
Bertarelli were unavailable for interviews, but a spokeswoman for the project says that they have not finalized their plans for the remainder of the site. A property consultancy is reviewing the proposal on Merck KGaA's behalf.

The move is the latest in a string of projects to transform former pharmaceutical-company sites into academic-industrial research hubs. In 2007, Yale University in New Haven, Connecticut, paid \$109 million for a local site vacated by Bayer. Two years later, the University of Michigan in Ann Arbor handed over $\$ 108$ million for a 28-building former Pfizer site, which the university turned into the North Campus Research Complex. And since Pfizer announced that it was pulling out of a large site in Sandwich, UK, last year (see Nature 470, $154 ; 2011)$, the British government has been trying to foster a science park there.

Both of the Swiss
"Within a year we can have people moving in and working there. That's an extraordinary opportunity." philanthropists certainly have the experience and the resources to make their plan work. Bertarelli's grandfather founded Serono, and Bertarelli was chief executive of the company before selling it to Merck KGaA in 2007. And in 2009, Wyss made a similar endowment to create the Wyss Institute for Biologically Inspired Engineering at Harvard University in Boston, Massachusetts.

Donald Ingber, director of the Harvard institute, says that it brings together former industry researchers, who have productdevelopment experience, with scientists working in basic biology. "What we've created is a start-up culture within an academic environment," he says. Although it is not yet clear whether a future Swiss Wyss centre would follow the same model, Ingber says, "I could see potentially great things coming out of that place".

\section{CORRECTION}

The source for the graphic 'Urban emitters' in the News story 'Megacities move to track emissions' (Nature 492, 20-21; 2012) should have been P. Romero Lankao et al. Clim. Res. 38, 17-29 (2008). 